\title{
Effect of Fenugreek (Trigonella foenum-gracum L.) Seed Powder as Natural Feed Additive on Growth Performance of Broilers
}

\author{
B.S. Gaikwad ${ }^{1}$, R.A. Patil ${ }^{2}$, P.V. Padghan ${ }^{3}$ and S.S. Shinde ${ }^{3^{*}}$ \\ Department of Animal Husbandry and Dairy Science, College of Agriculture, \\ Latur 413512, India \\ *Corresponding author
}

\section{A B S T R A C T}

Keywords

Growth performance, Feed intake, Feed conversion ratio, Economics

Article Info

Accepted:

10 September 2019

Available Online:

10 October 2019
The experimental trial was conducted to study the effect of fenugreek (Trigonella foenumgracum L.) seed powder as natural feed additive on growth performance, feed consumption and feed conversion ratio of broiler chicken. Study was conducted for six weeks eighty, day old, broiler chicks divided in four treatments of 20 chicks in each treatment with 4 replications of five chicks. The control $\left(T_{1}\right)$ group was fed with standard broiler ration and $T_{2}, T_{3}$ and $T_{4}$ groups were provided same broiler ration supplemented with 0.5 per cent, 1 per cent and 1.5 per cent fenugreek seed powder, respectively. The result showed that $1.5 \%$ supplemented feed diet increses cumulative weight, weight gain, feed intake but $1 \%$ supplemented feed diet best feed conversion ratio (1.87) was recorded. It was concluded that $1 \%$ of (FSP) in broiler diets can be used as natural feed additive for enhancing growth performance, feed conversion of broilers.

\section{Introduction}

The population in India is currently increasing at a rapid rate. At this time, one of the most important objectives is to supply the Indians with enough food. This means that the agricultural production has to be increased and the animal production continually has to be intensified with the exploitation of new food sources. On the other hand, the performance of the animal should be improved by the best breeding, feeding and using of factors which may have a positive effect on the food acceptability; texture and quality and on the animal side by altering digestion, absorption and metabolism to the most benefit. Indian economy majorly contributed by livestock and poultry sector. Poultry rearing is one of the most suitable activities to improve the livelihoods of the poor people due to the advantage that it requires small amount of capital and the relative ease to set-up such a production system in the rural communities. The broiler industry is growing at the rate of 12-15 per cent per annum during last few years. The total poultry production in country is 729.2 million.

The recent trend in the feed supplement is directed toward the use of natural ingredients 
as alternatives to antibiotics, synthetic colors and other chemicals. Feed additives are added to broilers diet to improve its productive performance by increasing growth rate, better feed conversion efficiency and greater livability in poultry birds. Leafy vegetables seed powder as an additive in the diet of chickens is very common.

Fenugreek (Trigonella foenum-graecum L.) is a well-known medicinal plant that grows in nature and mainly cultivated in India, Pakistan and china. Fenugreek seeds have many therapeutic effects like hypoglycaemic, antidiabetic, anti-fertility, anti-cancer, antiparasitic, anthelmintic, antibacterial, antiinflammatory, antipyretic, and antimicrobial properties (Bash et al., 2003). It contains neurin, biotin and trim ethylamine which tends to stimulate the appetite by their action on the nervous system (Al Habori and Roman, 2002). Since long Fenugreek is being used as a growth promoter particularly in the diet of broiler chicken. Inclusion of Fenugreek seeds in the diet significantly improves the body weight of broiler chicken (Abaza, 2007; Yatoo et al., 2012 and Quershi et al., 2015). Further, it improves the feed efficiency with reduction in feed cost when used as natural feed additive in broiler chicken diet (Azoua, 2001).

There are numerous feed additives of plant origin that are used in broiler feeds to improve the performance by enhancing growth rate, better feed conversion efficiency and lower mortality.

\section{Materials and Methods}

Eighty, day old, commercial straight run broiler chicks (Vencobb-430) strain was obtained from Huma-hatcheries, Latur (Maharashtra). All the experimental chicks were individually weighed wing banded and then randomly distributed in to four treatments of 20 chicks with four replication of 5 chicks in each treatment on similar body weight basis. All the experimental chicks were reared for 42 days on deep litter system in a wellventilated shed. Proper brooding of chicks was done by providing sufficient heat and light by using electric bulbs in each treatment for first three weeks of age. The standard temperature of brooding was $32-35^{\circ} \mathrm{C}$ for first week. A weekly reduction of $3^{0} \mathrm{C}$ was done till brooder temperature reaches to $27^{\circ} \mathrm{C}$ by third week of age. Afterword sufficient artificial light was provided during night hours throughout the experimental period.

Fresh, clean and cool drinking water was provided to bird's ad-labitum. All the precautionary measures against diseases were taken throughout the experimental period of six weeks. The dietary treatments $T_{1}-100$ parts of standard broiler ration without supplement (control group), $\mathrm{T}_{2^{-}} 99.5$ parts of standard broiler ration +0.5 Parts of fenugreek seed powder, $\mathrm{T}_{3^{-}} 99.00$ parts of standard broiler ration +1.00 Parts of fenugreek seed powder and $\mathrm{T}_{4}-98.5$ part standard broiler ration +1.5 Parts of fenugreek seed powder. All the broiler chicks were fed with ground maize first two days of age. Chicks feed standard feed for three periods as 2-10 days birds fed with pre-starter, 11-21 days birds fed with broiler starter and 22-42 days birds fed with broiler finisher. The diets were fed $a d$ libitum to experimental groups by adding required amount of fenugreek seed powder as per treatment. The per cent ingredient composition of experimental broiler ration that is for pre-starter, starter and finisher in Table 1 , respectively.

The birds were weighed every week to determine the average weight gain per chick for the different treatment groups. The feed was weighed every week to determine the average feed intake per chick for the different treatment groups. Feed intake was calculated by the remained feed and divided by the 
number of birds in each group per day and totalized to be per week.Feed conversion ratio It was recorded at weekly interval and calculated by dividing the total amount of feed consumed by body weight gain for each week. The treatment wise data on cumulative body weight gain in body weight, feed consumption and feed conversion ratio were subjected to analysis of variance of complete. randomized design (Snedecor and Cochran 1982).

\section{Results and Discussion}

\section{Growth performance of broilers}

\section{Cumulative body weights}

The average weekly growth performance of experimental birds at body weight of broilers from day old to sixth weeks of age in all dietary treatments were subjected to CRD and the results are presented in Table 2. The statistical analysis on the weekly body weight of broiler birds under four different treatments during each week revealed significant $(\mathrm{P}<0.05)$ difference during all the weeks except initial, first and second week. After the sixth week it was observed from the average cumulative body weights of broiler birds in the treatment group $\mathrm{T}_{3}$ and $\mathrm{T}_{4}$ were significantly $(\mathrm{P}<0.05)$ higher as compared to those in $T_{1}$ and $T_{2}$ group.

The average body weight of $2636.12 \mathrm{~g}$ obtained in $\mathrm{T}_{4}$ group was significantly superior over $\mathrm{T}_{1}(2536.47 \mathrm{~g})$ and those in $\mathrm{T}_{2}(2573.53$ g) group. The growth pattern indicated that optimum beneficial effect of fenugreek seed powder supplementation as an herbal feed additive could be achieved at 1.5 per cent level of inclusion but 1 per cent was economical because 1 per cent and 1.5 per cent levels were at par with each other. The improvement in body weights of birds in all fenugreek powder diet group was observed. It may be due to the presence of essential fatty acids and high quality proteins in the fenugreek seeds and stimulating effect of the digestive system might in turn lead to improve body weights and performance.

The results of present study were similar with Elbushra. (2012) who showed that the weekly gain in body weight of broiler chicks receiving 1.5 per cent fenugreek seed powder was significantly $(\mathrm{P}<0.05)$ higher as compared to control, group receiving 0.5 per cent and those in group receiving 1 per cent fenugreek seed powder. Similar trend was also observed by Weerasingha and Atapattu (2013) who reported the same result as the weekly live body weight of fenugreek fed 1 per cent fenugreek seed powder group of broiler remained significantly $(\mathrm{P}<0.05)$ higher than that of control group.

Mamoun et al., (2014) also revealed that chicks fed on 1\% FSP recorded significantly $(\mathrm{P}<0.05)$ higher body weight compared to all tested groups, while those fed on control diet recorded significantly lower body weight.Bhale (2015) also noticed similar results with present study that addition of $1 \%$ germinated fenugreek seed powder in broiler ration exhibited better weight than without germinated fenugreek seed powder. Khadr and Abdel-Fattah (2007) indicated that addition of fenugreek seeds during the growing period had slightly increased body weight gain for chicks fed diets containing $1 \%$ fenugreek seeds followed by those fed $2 \%$ as compared to control diet.

\section{Gain in body weight}

Average gain in body weight in $\mathrm{T}_{4}$ did not differed significantly with $T_{3}$ group. The treatment $\mathrm{T}_{1}$ control $(2489.14 \mathrm{~g})$ was significantly lower as compared to all the treatments i. e. $\mathrm{T}_{2}(2526.25 \mathrm{~g}), \mathrm{T}_{3}(2576.87 \mathrm{~g})$ and $\mathrm{T}_{4}(2588.69 \mathrm{~g})$. The average body weight gain of $2588.69 \mathrm{~g}$ obtain in $\mathrm{T}_{4}$ group was 
significantly superior over $\mathrm{T}_{1}(2489.14 \mathrm{~g})$ and $\mathrm{T}_{2}(2526.25 \mathrm{~g})$ (Table 3).

The results of the present study were comparable with Khadr and Abdel-Fattah (2007) they reported that addition of fenugreek seeds during the growing period had slightly increased body weight gain for chicks fed diets containing $1 \%$ fenugreek seeds followed by those fed $2 \%$ as compared to control diet. The similar observations were also reported by Alloui (2012) who showed that broiler chicks fed diet supplemented with fenugreek seed at $3 \mathrm{~g} / \mathrm{kg}$ of feed had significantly $(\mathrm{P}<0.05)$ higher live body weight (LBW) at 21 to 42 days of age. The fenugreek group showed highest weight gain as compared to the control group.

\section{Feed intake}

The weekly and cumulative feed consumption per bird was calculated from 0-6 week's period and presented in Table 4. The data on the feed consumption of experimental broiler birds under various experimental treatments recorded during the six weeks period were subjected to CRD and the results are presented in Table 4. It may be seen that significant differences among the all treatment groups except first and second week, where as significantly differences were recorded after third week up to end of experiment.

At the end of experiment the total feed consumed by different treatment groups broiler chicks as $\mathrm{T}_{3}$ group consumed significantly $(\mathrm{P}<0.05)$ lower quantity of feed $(4839.42 \mathrm{~g})$ as compared to $\mathrm{T}_{4}(5203.81 \mathrm{~g})$ and $\mathrm{T}_{2}(5097.35 \mathrm{~g})$. It could be seen that highest feed consumption of $5203.81 \mathrm{~g}$ was obtained in $\mathrm{T}_{4}$ group broilers receiving 1.5 per cent fenugreek seed powder followed by $5114.77 \mathrm{~g}$ with control in $\mathrm{T}_{1}, 5097.35 \mathrm{~g}$ in $\mathrm{T}_{2}$ and lowest feed consumption i. e. $4839.42 \mathrm{~g}$ in $\mathrm{T}_{3}$ at the end of $6^{\text {th }}$ week. It showed that the birds fed with highest level of fenugreek seed powder had highest feed consumption rate in the broiler birds.

Whereas, Saber Beghoulet. al. (2017)observed that addition of fenugreek into drinking water increased feed consumption by about $295.5 \mathrm{~g}$ compared to control chickens. This may be due to the presence of antiproteolytic substance. Tariq et al., (2014) also reported that the birds fed on diet containing 1,2 and $3 \%$ fenugreek seed significantly $(\mathrm{P}<0.05)$ increased the feed intake. Khadr and AbdelFattah (2007) reported that there was slight increase in feed intake with addition of $2 \%$ fenugreek in diet. This result can be attributed to the presence of steroid saponins (appetitestimulating) in fenugreek seeds which increased feed intake and motivation to eat.

Qureshi et al., (2015) noted that the cumulative feed consumption was highest $(\mathrm{P}<0.05)$ in all the groups in fenugreek seeds were supplemented when compared with the control group. These results were contaradictory to Dura Metin et al., (2013) and Weerasingha and Atapattu (2013) who reported that the birds fed with 5\% fenugreek seed powder consumed significantly $(\mathrm{P}<0.01)$ less amount of feed compared to control group.

\section{Feed conversion ratio}

The mean weekly feed conversion ratio in terms of feed intake per unit gain in weight for different dietary groups during $1^{\text {st }}$ to $6^{\text {th }}$ week were calculated from following the data.

It was revealed from Table 5 that average feed conversion ratio from first to sixth week ranged from 1.87 to 2.05 which was significantly $(\mathrm{P}<0.05)$ higher in $\mathrm{T}_{3}(1.87)$ as compared to $\mathrm{T}_{4}(2.01), \mathrm{T}_{2}(2.01)$ and $\mathrm{T}_{1}$ control (2.05) group. 
Table.1 Chemical composition of experimental broiler ration

\begin{tabular}{|l|l|c|c|c|}
\hline \multirow{2}{*}{$\mathbf{S}$ No. } & \multirow{2}{*}{ Nutrients } & \multicolumn{3}{|c|}{ Per cent in ration } \\
\cline { 3 - 5 } & & Pre-starter & Starter & Finisher \\
\hline $\mathbf{1}$ & Crude protein & 23.35 & 21.64 & 20.20 \\
\hline $\mathbf{2}$ & Crude fibre & 3.92 & 3.96 & 3.99 \\
\hline $\mathbf{3}$ & Ether extract & 4.95 & 5.08 & 5.12 \\
\hline $\mathbf{4}$ & Total ash & 6.2 & 6.1 & 5.93 \\
\hline $\mathbf{5}$ & Acid insoluble ash & 1.57 & 1.60 & 1.62 \\
\hline $\mathbf{6}$ & Nitrogen free extract & 61.58 & 63.22 & 64.76 \\
\hline $\mathbf{7}$ & Metabolizable energy $(\mathrm{kcal} / \mathrm{kg})$ & 2982.5 & 3065.7 & 3198.8 \\
\hline $\mathbf{8}$ & E/P ratio & $127.73: 1$ & $141.66: 1$ & $158.35: 1$ \\
\hline
\end{tabular}

Table.2 Average weekly cumulative body weight (g) per bird

\begin{tabular}{llccccc}
\hline Items & & \multicolumn{5}{c}{ Fenugreek seed powder levels } \\
\cline { 3 - 7 } & $\begin{array}{l}0 \% \\
\left(\mathrm{~T}_{1}\right)\end{array}$ & $\begin{array}{c}0.5 \% \\
\left(\mathrm{~T}_{2}\right)\end{array}$ & $\begin{array}{c}1 \% \\
\left(\mathrm{~T}_{3}\right)\end{array}$ & $\begin{array}{c}1.5 \% \\
\left(\mathrm{~T}_{4}\right)\end{array}$ & $\mathrm{SE}$ & $\mathrm{CD}$ \\
\hline Initial & 47.33 & 47.28 & 47.28 & 47.43 & 0.08 & $\mathrm{NS}$ \\
\hline $1^{\text {st }}$ week & 189.50 & 189.25 & 190.15 & 190.25 & 0.86 & $\mathrm{NS}$ \\
\hline $2^{\text {nd }}$ week & 443.33 & 438.38 & 441.56 & 442.47 & 2.63 & $\mathrm{NS}$ \\
\hline $3^{\text {rd }}$ week & $877.50^{\mathrm{a}}$ & $884.54^{\mathrm{a}}$ & $897.48^{\mathrm{b}}$ & $903.44^{\mathrm{b}}$ & 2.76 & 8.51 \\
\hline $4^{\text {th }}$ week & $1388.25^{\mathrm{a}}$ & $1404.57^{\mathrm{b}}$ & $1427.17^{\mathrm{c}}$ & $1428.48^{\mathrm{c}}$ & 2.79 & 8.60 \\
\hline $5^{\text {th }}$ week & $2001.15^{\mathrm{a}}$ & $2035.55^{\mathrm{b}}$ & $2068.56^{\mathrm{c}}$ & $2074.50^{\mathrm{c}}$ & 2.95 & 9.10 \\
\hline $6^{\text {th }}$ week & $2536.47^{\mathrm{a}}$ & $2573.53^{\mathrm{b}}$ & $2624.15^{\mathrm{c}}$ & $2636.12^{\mathrm{c}}$ & 19.65 & 19.65 \\
\hline
\end{tabular}

Note: (Significant $(\mathrm{P}<0.05)$ means under each class in the same column with different superscripts differ significantly) 
Table.3 Average weekly gain in body weight (g) per bird

\begin{tabular}{lcccccc}
\hline Items & \multicolumn{5}{c}{ Fenugreek seed powder levels } \\
\cline { 3 - 7 } & $\begin{array}{l}0 \% \\
\left(\mathrm{~T}_{1}\right)\end{array}$ & $\begin{array}{c}0.5 \% \\
\left(\mathrm{~T}_{2}\right)\end{array}$ & $\begin{array}{c}1 \% \\
\left(\mathrm{~T}_{3}\right)\end{array}$ & $\begin{array}{c}1.5 \% \\
\left(\mathrm{~T}_{4}\right)\end{array}$ & $\mathrm{SE}$ & $\mathrm{CD}$ \\
\hline $1^{\text {st }}$ week & 142.18 & 141.98 & 142.88 & 142.85 & 0.81 & NS \\
\hline $2^{\text {nd }}$ week & 253.83 & 249.13 & 251.41 & 225.22 & 02.73 & NS \\
\hline $3^{\text {rd }}$ week & $434.18^{\mathrm{a}}$ & $446.16^{\mathrm{ab}}$ & $455.92^{\mathrm{bc}}$ & $460.97^{\mathrm{c}}$ & 04.24 & 13.06 \\
\hline $4^{\text {th }}$ week & $510.84^{\mathrm{a}}$ & $520.04^{\mathrm{a}}$ & $529.68^{\mathrm{ab}}$ & $525.04^{\mathrm{b}}$ & 03.47 & 10.70 \\
\hline $5^{\text {th }}$ week & $612.81^{\mathrm{a}}$ & $630.98^{\mathrm{b}}$ & $641.39^{\mathrm{bc}}$ & $646.02^{\mathrm{c}}$ & 03.86 & 11.92 \\
\hline $6^{\text {th }}$ week & $535.30^{\mathrm{a}}$ & $537.96^{\mathrm{ab}}$ & $555.59^{\mathrm{bc}}$ & $561.59^{\mathrm{c}}$ & 06.15 & 18.95 \\
\hline Total & $2489.14^{\mathrm{a}}$ & $2526.25^{\mathrm{b}}$ & $2576.87^{\mathrm{c}}$ & $2588.69^{\mathrm{c}}$ & 06.34 & 19.54
\end{tabular}

Note: (Significant $(\mathrm{P}<0.05)$ means under each class in the same column with different superscripts differ significantly)

Table.4 Feed intake of broiler chicks as affected by addition of moringa olifera leaf meal

\begin{tabular}{lllllll}
\hline Items & & \multicolumn{5}{c}{ Fenugreek seed powder levels } \\
\cline { 3 - 7 } & $0 \%$ & $0.5 \%$ & $1 \%$ & $1.5 \%$ & SE & CD \\
& $\left(\mathrm{T}_{1}\right)$ & $\left(\mathrm{T}_{2}\right)$ & $\left(\mathrm{T}_{3}\right)$ & $\left(\mathrm{T}_{4}\right)$ & & \\
\hline $1^{\text {st }}$ week & 190.31 & 188.35 & 188.43 & 190.42 & 01.22 & NS \\
\hline $2^{\text {nd }}$ week & 302.16 & 300.35 & 292.21 & 305.64 & 03.07 & NS \\
\hline $3^{\text {rd }}$ week & $799.84^{\mathrm{a}}$ & $795.26^{\mathrm{c}}$ & $749.25^{\mathrm{b}}$ & $810.51^{\mathrm{c}}$ & 01.78 & 5.50 \\
\hline $4^{\text {th }}$ week & $925.47^{\mathrm{a}}$ & $922.47^{\mathrm{a}}$ & $862.17^{\mathrm{b}}$ & $951.50^{\mathrm{c}}$ & 02.05 & 6.31 \\
\hline $5^{\text {th }}$ week & $1400.69^{\mathrm{a}}$ & $1397.55^{\mathrm{b}}$ & $1325.28^{\mathrm{c}}$ & $1432.08^{\mathrm{d}}$ & 02.63 & 8.11 \\
\hline $6^{\text {th }}$ week & $1496.30^{\mathrm{a}}$ & $1493.37^{\mathrm{a}}$ & $1422.08^{\mathrm{b}}$ & $1513.66^{\mathrm{c}}$ & 03.36 & 10.37 \\
\hline Total & $5114.77^{\mathrm{a}}$ & $5097.35^{\mathrm{a}}$ & $4839.42^{\mathrm{b}}$ & $5203.81^{\mathrm{c}}$ & 08.80 & 27.13 \\
\hline
\end{tabular}

Note: (Value superscripted differently, differs significantly $(\mathrm{P}<0.05)$ within a column) 
Table.5 Average weekly feed conversion ratio of experimental birds.

\begin{tabular}{lcccccc}
\hline Items & & \multicolumn{5}{c}{ Fenugreek seed powder levels } \\
\cline { 3 - 7 } & $\begin{array}{c}0 \% \\
\left(\mathrm{~T}_{1}\right)\end{array}$ & $\begin{array}{c}0.5 \% \\
\left(\mathrm{~T}_{2}\right)\end{array}$ & $\begin{array}{c}1 \% \\
\left(\mathrm{~T}_{3}\right)\end{array}$ & $\begin{array}{c}1.5 \% \\
\left(\mathrm{~T}_{4}\right)\end{array}$ & SE & C.D \\
\hline $1^{\text {st }}$ week & 1.34 & 1.32 & 1.32 & 1.33 & 0.01 & $\mathrm{NS}$ \\
\hline $2^{\text {nd }}$ week & $1.19^{\mathrm{ab}}$ & $1.20^{\mathrm{a}}$ & $1.16^{\mathrm{b}}$ & $1.21^{\mathrm{a}}$ & 0.01 & 0.03 \\
\hline $3^{\text {rd }}$ week & $1.84^{\mathrm{a}}$ & $1.78^{\mathrm{b}}$ & $1.64^{\mathrm{c}}$ & $1.75^{\mathrm{b}}$ & 0.01 & 0.03 \\
\hline $4^{\text {th }}$ week & $1.81^{\mathrm{a}}$ & $1.77^{\mathrm{a}}$ & $1.62^{\mathrm{b}}$ & $1.81^{\mathrm{a}}$ & 0.01 & 0.04 \\
\hline $5^{\text {th }}$ week & $2.28^{\mathrm{a}}$ & $2.21^{\mathrm{b}}$ & $2.06^{\mathrm{c}}$ & $2.21^{\mathrm{b}}$ & 0.01 & 0.04 \\
\hline $6^{\text {th }}$ week & $2.79^{\mathrm{a}}$ & $2.77^{\mathrm{a}}$ & $2.56^{\mathrm{c}}$ & $2.69^{\mathrm{b}}$ & 0.03 & 0.09 \\
\hline Overall & $2.05^{\mathrm{a}}$ & $2.01^{\mathrm{b}}$ & $1.87^{\mathrm{c}}$ & $2.01^{\mathrm{b}}$ & 0.03 & 0.014 \\
\hline
\end{tabular}

Note: $\left({ }^{\mathrm{acc}}\right.$ Value with no common superscript are significantly different $(\mathrm{P}<0.05)$ within a column)

Table.6 Economics of broiler production per bird

\begin{tabular}{|c|c|c|c|c|c|}
\hline \multirow{2}{*}{$\begin{array}{l}\text { Sr. } \\
\text { No }\end{array}$} & \multirow[t]{2}{*}{ Particular } & \multicolumn{4}{|c|}{ Treatments } \\
\hline & & $\mathbf{T}_{1}$ & $\mathbf{T}_{2}$ & $\mathbf{T}_{3}$ & $\mathbf{T}_{4}$ \\
\hline 1. & Cost of day old chicks (Rs.) & 41 & 41 & 41 & 41 \\
\hline 2. & Fenugreek consumed per bird (g) & 0 & 25.48 & 48.39 & 78.05 \\
\hline 3. & Cost of Fenugreek (Rs./g) & - & 0.07 & 0.07 & 0.07 \\
\hline 4. & Cost of Fenugreek (Rs.) & 0 & 1.78 & 3.38 & 5.46 \\
\hline 5. & Avg. Total feed consumed per bird (g) & 5114.77 & 5097.35 & 4839.42 & 5203.81 \\
\hline 6. & Cost of feed (Rs./Kg) & 26 & 26 & 26 & 26 \\
\hline 7. & Cost of feed consumed per bird Rs. & 132.96 & 132.52 & 125.81 & 135.27 \\
\hline 8. & $\begin{array}{l}\text { Total cost of feed consumed per bird Rs. } \\
(4+7)\end{array}$ & 132.96 & 134.3 & 129.19 & 140.73 \\
\hline 9. & Avg. Body weight at the end of $6^{\text {th }}$ week ( $g$ ) & 2536.47 & 2573.53 & 2624.15 & 2636.12 \\
\hline 10. & Feed consumption per kg live weight $(\mathrm{g})$ & 2016.49 & 1980.68 & 1844.41 & 1974.03 \\
\hline 11. & Cost of feed per kg live weight gain (Rs.) & 52.42 & 52.18 & 49.23 & 53.38 \\
\hline 12. & $\begin{array}{l}\text { Cost of medicine, vaccine and litter material } \\
\text { per bird (Rs.) }\end{array}$ & 5 & 5 & 5 & 5 \\
\hline 13. & Cost of Production $(1+8+12)$ Per bird (Rs.) & 178.96 & 180.3 & 175.19 & 186.73 \\
\hline 14. & $\begin{array}{l}\text { Avg. Price realized @ Rs. } 80 \text { Per kg live } \\
\text { weight (Rs.) }\end{array}$ & 202.91 & 205.88 & 209.93 & 210.88 \\
\hline 15. & Net profit per bird (14-13) Rs. & 23.95 & 25.58 & 34.74 & 24.15 \\
\hline
\end{tabular}


It was revealed from Table 5 that the best feed conversion ratio of 1.87 obtained in $\mathrm{T}_{3}$ group broilers receiving 1 per cent fenugreek seed powder followed by 2.01 with 0.5 per cent in $\mathrm{T}_{2}, 2.05$ in $\mathrm{T}_{4}$ group receiving 1.5 per cent fenugreek seed powder and poor in feed conversion i. e.2.05 in $\mathrm{T}_{1}$ control at the end of 6 th week. It showed that the 1 per cent level of fenugreek seed powder increased highest feed conversion ratio in broiler birds.

The results were in line with findings of Bhale (2015) who reported better feed conversion ratio in treatment bird fed with $1 \%$ germinated fenugreek seed powder compared to birds fed with $1.5 \%$ and $2 \%$ germinated fenugreek seed powder. Similar results were also found by that Weerasingh and atapattu (2013) who observed that the bird fed 1\% fenugreek had best FCR.1\% fenugreek seed powder showed some positive effect and give better FCR than control group.

Same results were found by Yatoo (2014) who conducted an experiment on broiler using different feed additives, $\mathrm{T}_{1}$ - no feed additive, $\mathrm{T}_{2}-1 \%$ fenugreek, $\mathrm{T}_{3}-1 \%$ black cumin and $\mathrm{T}_{4}-0.5 \%$ each of fenugreek and black cumin and reported that there was higher $(\mathrm{p}<0.01)$ feed intake in all the treatment groups compared to control. The result of present study support the findings of Alloui Nadir (2012), Elbushra (2012), and Mamounet al., (2014) where they reported significant $(\mathrm{P}<0.05)$ improvement of FCR in all treatments groups fed with different feed additives compared to control group fed without any feed additives.

\section{Economics of broiler production}

The cost (Rs.) of feed per $\mathrm{kg}$ live weight gain was highest for $\mathrm{T}_{4}$ (53.38) followed by $\mathrm{T}_{1}(52.42)$ group, $\mathrm{T}_{2}(52.18)$ and lowest for the $\mathrm{T}_{3}$ (49.23) group. The live body weight was highest in treatment $\mathrm{T}_{4}(2636.12 \mathrm{~g})$, followed by $\mathrm{T}_{3}(2624.15 \mathrm{~g}), \mathrm{T}_{2}(2573.53 \mathrm{~g})$ and $\mathrm{T}_{1}$ $(2536.47 \mathrm{~g})$ control group. The net profit per bird was highest in $\mathrm{T}_{3}$ (Rs. 34.74) followed by $\mathrm{T}_{2}$ (Rs. 25.58), $\mathrm{T}_{4}$ (Rs. 24.15) and lowest in $\mathrm{T}_{1}$ control (Rs. 23.95). Nevertheless, on the basis of cost of feed required for one $\mathrm{kg}$ live weight in treatment $\mathrm{T}_{3}$ was economical for broiler production as compared to other treatments and control group. The results indicated that the performance of broilers in $\mathrm{T}_{3}$ group was superior than that of the control and other treatments and 1 per cent level of fenugreek in broiler diet seems to be economical.

These results were partially in agreement with Abaza (2007) and Abdel Rahman et al., (2014) who recorded that birds fed with $1 \%$ fenugreek gave highest profit. Bhale (2015) also found similar results with this experiment and reported that broilers feeding with one per cent germinated fenugreek seed powder was the most effective for obtaining high returns per bird (Table 6).

The results of economical evaluations of the experimental diets showed that the supplementation of FSP to broiler diets improved the performance of chicks and resulted economic benefits. Profitability ratio (2.79) for broilers fed with 1\% FSP was the highest although all chicks fed on different levels recorded high ratio of profits compared to control group these result were in agreement with findings of Mukhtar et. al. (2013).

In conclusion, this study indicated that supplementation of fenugreek seed powder at the difference levels of $0.5 \%, 1.0 \%$ and 1.5 $\%$ in the broiler chick's diet. The inclusion of 1.5 per cent of fenugreek seed powder in broiler diet as a herbal feed supplement is beneficial in improving the live weight, weight gain feed consumption but feed conversion ratio superior in 1 per cent fenugreek seed powder. The inclusion of 1 
per cent of fenugreek in broiler diet as a herbal feed supplement is economical.The feeding of fenugreek is economical as it improved overall performance of broilers and increased margin of profit in broiler production. The feeding of fenugreek seed powder is beneficial as a growth promoter or feed supplement in commercial broiler production.

\section{References}

Abaza I.M. (2007). Effects of Using Fenugreek, Chamomile and Radish as Feed Additives on Productive Performance and Digestibility Coefficients of Laying Hens. Poult.Sci, 199-218.

Alloui, N., S. Ben Aksa, M. N. Alloui and F. Ibrir (2012). Utilization of Fenugreek (Trigonella foenum-Graecum) as Growth Promoter for Broiler Chickens. J. World's Poult. Res.,2(2): 25-27.

Anonymous (2012). 19 ${ }^{\text {th }}$ Livestock Census of India Government of India New Delhi. A.O.A.C (1995).Official Methods of Analysis, $16^{\text {th }}$ ed. Association of Official Analytical Chemist, Washington, D.C.

Azoua H. M. (2001). Effect of Hot Pepper and Fenugreek Seeds Supplementation on Broiler Diets. Ph. D.Thesis, Submitted to Faculty of Agriculture, Alexandria University, Egypt.

Bash E, Ulbricht C, Kuo, G, Szapary P et Smith M (2003). Therapeutic Applications of Fenugreek. Alternative Medicine Review, 8: 20-27.

Beghoul, S., Abdeldjelil, M.C., Benazzouz, H., Messai, A., Chouah, B., and Mansour, A. (2017). Fenugreek (Trigonellafoenum-graecum)

an

Alternative Antistress in Broiler Chickens in Algeria Scholars Research Library Der Pharmacia Lettre, 9(1):6469.
Bhale C.T. (2015).Effect of germinated Fenugreek (TrigonellaFoenumGraecum.L) Seed Powder on Performance of Broiler Chicken. M. V.Sc. Thesis, Submitted to MAFSU, Nagpur (M.S).

Elbushra M. E. (2012). Effect of Dietary Fenugreek Seeds (Trigonellafoenum) as Natural Feed Addition on Broiler Chicks Performance J. of Sci. and Technology Vol. 13 Agricultural and Veterinary Sciences (JAVS No. 2). 2731.

Khadr N.A., and Abdel-Fattah F.A.I., (2007). Response of Broiler Chickens to Diet Containing Fenugreek Seed (TrigonellaFoenum- Graecum L.) as a Natural Feed Additive Benha Vet.Med.J., 18.1:237-257.

Mamoun, T., M. A .Mukhtar and M.H. Tabidi (2014). Effect of Fenugreek Seed Powder on the Performance, Carcass Characteristics and Some Blood Serum Attributes. Adv. Res. Agri. Vet. Sci., 1(1): 6-11.

Mukhtar Ahmed Mukhtar.,Tariq Mamoun and Mohamed H Tabidi (2014).Effect of Fenugreek Seed Powder on the Performance, Carcass Characteristics and Some Blood Serum Attributes. Advance Research in Agriculture and Veterinary Science, 1(1): 6-11.

Qureshi Saim., Banday, M.T., Sheikh Adil., IrfanShakeel and Munshi, Z.H (2015). Effect of Dandelion Leaves and Fenugreek Seeds With or Without Enzyme Addition on Performance and Blood Biochemistry of Broiler Chicken, and Evaluation of Their in vitro Antibacterial Activity.Indian J.Anim. Sci., 85(11): 1248-1254.

Snedecor,G.W. and W.G. Cochran, (1982). Statistical Methods. 6th Edition, Oxford and IBH Publishing co. Culcutta, Bombay and Delhi: 168-181.

Weerasingha A.S.and Atapattu N.S.B.M. 
(2013). Effect of Fenugreek (Trigonellafoenum-graecum L.) Seed powder on Growth Performance, Visceral Organ Weight, Serum Cholesterol Levels and the Nitrogen Retention of Broiler Chicken, Tropical Agricultural Research,24(3): 289-295.
Yatoo, M. A., R.K. Sharma, N. Khan, A. Rastogi, and A. K. Pathak (2012).Effect of Fenugreek and Black Cumin Seeds as Feed Additives on Blood Biochemical Profile and Performance of Broilers. Indian J. Anim. Nutri., 29(2): 174-178

\section{How to cite this article:}

Gaikwad, B.S., R.A. Patil, P.V. Padghan and Shinde, S.S. 2019. Effect of Fenugreek (Trigonella foenum-gracum L.) Seed Powder as Natural Feed Additive on Growth Performance of Broilers. Int.J.Curr.Microbiol.App.Sci. 8(10): 1137-1146.

doi: https://doi.org/10.20546/ijcmas.2019.810.133 